\title{
СПАДКУВАННЯ НА ОКРЕМИХ ТЕРИТОРІЯХ УКРАїнИ
}

\author{
ЧУЙКОВА Валентина Юрї̈вна - кандидат юридичних наук, доцент, доцент \\ кафедри цивільного права №2 Національного юридичного університету імені \\ Ярослава Мудрого
}

ORCID ID: 0000-0002-2239-8377

ГОНЧАРОВА Аліна В'ячеславівна - кандидат юридичних наук, доцент, доцент кафедри кримінально-правових дисциплін та судочинства, Навчальнонауковий інститут права, Сумський державний університет

ORCID ID: 0000-0002-9815-0394

У изій статті розкрито питання особливостей спадкування в зоні АТО та на окупованих територіях. Враховано нововведення, які вступили в силу з 2018 року. Зазначено, шо окуповані територї у Донецькій та Ауганській областях визнаються частини територї Украӥни, у межах яких збройні формування РФ та окупаиійна адміністраиія РФ встановили та здійснюють загальний контроль. Тимчасова окупаиія РФ територій украӥни, незалежно від $\dddot{\imath}$ тривалості, $\varepsilon$ незаконною $i$ не створюе для РФ жодних територіальних прав. y межах тимчасово окупованих територій diє особливий порядок забезпечення прав і свобод ичивільного населення, визначений законодавством Украӥни. Тому процедура оббормлення спадщини $\epsilon$ незмінною по всій територї̈ Украйни.

Було проаналізовано інбормащію щодо порядку отримання спадщини за законом, за заповітом та при укладенні спадкового договору. Акцентовано увагу, що спадкування - це не тільки похідний спосіб виникнення права власності, а також універсальне правонаступнищтво - перехід всъого комплексу прав, обов'язків, речей від померлої особи до спадкоємиів.

Разом з тим, своєчасне і чітке виконання своїх зобов'язань надає можливість вчасно обормити спадщину, відповідно до норм законів. Спадкування за заповітом відбувається у випадку, якщо померлою особою до смерті було складено заповіт i він $є$ дійсним. У разі його відсутності відбувається спадкування за законом. Спадкування за законом має місие в таких випадках: відсутності заповіту; визнання заповіту недійсним; смерті спадкоємиів, вказаних у заповіті до відкриття спадщини або їх відмови від прийняття спадщи- ни; заповідачем скасовано раніше складений заповіт і не залишено нового; заповіт у судовому порядку визнано недійсним; у разі, якщо заповітом не охоплено усъого майна, що належало спадкодавцю.

Ключові слова: спадкоємець, спадкодавещь, спадиина, спадкове законодавство, свідоцтво про право на спадщину, правовий режим.

\section{Постановка проблеми}

Сучасні українські реалії потребують роз'яснення принципів оформлення спадщини на підконтрольних територіях. У зв'язку з цим, виникло нагальне питання роз'яснення загальних принципів процедури спадкування та аналіз нормативного закріплення.

Аналіз останніх досліджень i публікацій

Це питання вивчалося вітчизняними науковцями не в значній мірі. Звісно, не слід вважати, що науковці повністю ігнорують цю проблематику. Зокрема, можна згадати, тему спадкування розглядали Фулей T.I. [3], Федорич І.Я. [6]. Не применшуючи доробку зазначених науковців, слід звернути увагу, що спадкування в спірних ситуаціях здебільшого розглядалося узагальнено.

\section{Цілі і завдання}

Ціль полягає у формуванні розуміння здійснення права на спадкування, розробці нових рекомендацій, спрямованих на розв'язання виявлених проблем та по- 
дальше вдосконалення законодавчого регулювання відносин, що виникають під час здійснення спадкових прав у зоні АТО та на окупованих територіях. Необхідно вирішити наступні завдання: розкрити сутність поняття «право на спадкування»; проаналізувати порядок прийняття спадщини та відмови від спадщини; виявити особливості процедури здійснення права на спадкування шляхом подання заяви про прийняття спадщини в органи нотаріату.

\section{Виклад основного матеріалу}

Особливості правового режиму на території АРК та міста Севастополя визначаються Законом України від 15.04.2014 p. №1207-VII (в редакції від 17.06.2020р.) “Про забезпечення прав і свобод громадян та правовий режим на тимчасово окупованій території України" [2]. Особливості державної політики із забезпечення державного суверенітету України на тимчасово окупованих територіях у Донецькій та Ауганській областях визначаються Законом України від 18. 01. 2018 р. №2268-VIII (в редакції від 26.11.2020р.) “Про особливості державної політики із забезпечення державного суверенітету України на тимчасово окупованих територіях у Донецькій та Ауганській областях" [3].

Стаття 1 Закону України №1207-VII визначає, що тимчасово окупована територія України є невід'ємною частиною території України, на яку поширюеться дія Конституції та законів України.

Згідно зі статтею 1 Закону України №2268-VIII, тимчасово окупованими територіями у Донецькій та Ауганській областях визнаються частини території України, у межах яких збройні формування РФ та окупаційна адміністрація РФ встановили та здійснюють загальний контроль. Тимчасова окупація РФ територій України, незалежно від іiі тривалості, 6 незаконною і не створює для РФ жодних територіальних прав.

Діяльність збройних формувань РФ та окупаційної адміністрації РФ $є$ незаконною, а будь-який виданий у зв'язку з такою діяльністю акт $є$ недійсним і не створює жодних правових наслідків, крім докумен- тів, що підтверджують факт народження або смерті особи на тимчасово окупованих територіях, які додаються відповідно до заяви про державну реєстрацію народження особи та заяви про державну реєстрацію смерті особи.

Внаслідок окупації частини території України, з березня 2014 року у ії складі з'явилися території із спірним статусом. Включення окупованих територій України до складу РФ не отримало ні міжнародного, ні закордонного визнання. Відповідно, для інших країн та їх юрисдикцій, у тому числі у сфері спадкового права, застосування на цих територіях російського законодавства не має правових наслідків, у тому числі в частині відносин власності і спадкування.

У світі налічується біля 70 територій із схожим статусом, і проблема захисту власності та інших майнових прав на цих територіях періодично виникає із різним ступенем гостроти і стає предметом розгляду різних інстанцій, у першу чергу Европейського суду з прав людини ( ССП $)$ [4, с. 9].

Для сфери приватно-правового регулювання і спадкового права суттєве значення мають положення ст. 9 Закону України “Про забезпечення прав і свобод громадян та правовий режим на тимчасово окупованій території України", відповідно з якою будь-які органи,їх посадові і службові особи на тимчасово окупованій території вважаються незаконними, якщо ці органи і посадові особи були створені, обрані, призначені у порядку, не передбаченому законом. Відповідно, будь-які акти, рішення і документи нелегітимних органів вважаються недійсними і не тягнуть правових наслідків. Ст. 11 Закону регулює питання власності і встановлює правовий режим майна на тимчасово окупованій території. Набуття та припинення права власності на нерухоме майно, яке знаходиться на тимчасово окупованій території, здійснюється відповідно до законодавства України за межами окупованої території. У той же час на спірній території будь-яка угода, яка здійснена з порушенням вимог цього Закону і інших законів України, вважається недійсною 3 моменту укладення. 


\section{Цивільне, підприсмницьке, господарське та трудове право}

Закон України №1207-VII доповнено статтею 11-1 згідно із Законом України від 12.02.2015 р. № 189-VIII “Забезпечення реалізації права на спадкування”, яка визначає особливості здійснення права на спадкування. У випадку, якщо місцем смерті спадкодавця є тимчасово окупована територія, місцем відкриття спадщини вважається місце подачі спадкоємцями або іншими зацікавленими особами заяв про спадщину (про прийняття спадщини, відмови від прийняття, пред'явлення кредиторами спадкодавця претензій до спадкоємців тощо).

Аналогічне положення щодо спадкових правовідносин, які виникли у зв'язку з відкриттям спадщини на території окремих районів Донецької та Ауганської областей, у зоні проведення антитерористичної операції (ст.9-1 Закону України від 2.09.2014p. №1669- VII (в редакції від 27.12.2019р.) “Про тимчасові заходи на період проведення антитерористичної операції"[5].

Закон, яким було введене це правило, вступив у силу 4.03.2015 р. і в ньому відсутня вказівка щодо його застосування до спадщини, яка відкрилася, але не була прийнятою ніким до набрання ним чинності (розд. 2 Закону України №189-VIII). Закон застосовується до відносин, які виникли після набрання ним чинності. Проте, якщо відносини виникли до набрання ним чинності, відповідні норми застосовуються до тих прав та обов'язків, які виникли і продовжують існувати після набрання чинності Закону. Тобто Закон може застосовуватися і в тому випадку, коли спадщина відкрилася до набрання ним чинності, але не була ніким із спадкоємців прийнята. У силу положень Закону України “Про забезпечення прав і свобод громадян на тимчасово окупованій території України”, набуття права власності, інших прав та обов'язків у порядку спадкування у випадку, якщо спадщина відкрилася на території АРК і м. Севастополя, може здійснюватися тільки за законодавством України. Відповідно, спадщина оформлена на підставі законодавства Російської Федерації не тягне у спадкоємців права власності на спадкове майно. Відповідно до Конвенції про правову допомогу та правові відносини у цивільних, сімейних та кримінальних справах ( від 22.03.1993 р.), право спадкування майна визначається за законодавством сторони, яка домовляється, на території якої спадкодавець мав останне постійне місце проживання. При цьому право спадкування нерухомого майна визначається за законодавством Сторони, яка домовляється, на території якої знаходиться це майно (ст. 45 Конвенції) [6].

Фактично процедура оформлення спадщини починається 3 подання заяви нотаріусу. Основним документом для відкриття спадкової справи є свідоцтво про смерть спадкодавця. За нашими даними, такі свідоцтва на українських бланках зараз видаються на непідконтрольних територіях, але юридичної сили вони не мають у силу того, що не зареєстровані в українських реєстрах. Тому слід подбати про отримання довідки 3 медичної установи про смерть спадкодавця на території АТО і оформляти свідоцтво про смерть вже в органах реєстрації актів цивільного стану на території України. Якщо ж довідка уже здана і свідоцтво про смерть отримано на непідконтрольній території, то необхідно ініціювати судовий процес щодо встановлення факту смерті, що дозволить отримати юридичну підставу для відкриття спадкової справи.

Здійснення права на спадкування характеризує ставлення суб'єкта, у якого це право виникло, до самого права і правових наслідків його реалізації. Право на спадкування складається 3 правомочностей, що виникли у зв'язку з відкриттям спадщини та закликанням особи до спадкування, на підставі волевиявлення (заповіту) або закону. Волевиявленням особи формується сукупність іï майбутніх правомочностей, які також законодавець відносить до категорії здійснення права на спадкування. Таким чином, позиції науковців щодо визначення поняття здійснення права в основному будуються на двох основних концепціях розуміння суб'єктивного права як міри можливої поведінки, або ж як використання можливостей закладених у праві$[7$, c. 57]. 
Необхідно дотримуватися строків, встановлених Цивільним кодексом України. Загальний строк для прийняття спадщини встановлений у шість місяців, і його обчислення починається відповідно до ч. 1 ст. 1220 ЦК України 3 дня відкриття спадщини. Строк у шість місяців для здійснення спадкоємцями права на спадкування (прийняття, неприйняття, відмова, скасування актів прийняття чи відмова від спадщини) стосується насамперед спадкоємців за заповітом та спадкоємців, які мають право на обов'язкову частку у спадщині. Відповідно до ст. 1241 ЦК України ними можуть бути малолітні, неповнолітні, повнолітні непрацездатні діти спадкодавця, непрацездатна вдова (вдівець) та непрацездатні батьки. Визначені особи спадкують, незалежно від змісту заповіту, половину частки, яка належала 6 кожному 3 них у разі спадкування за законом (обов'язкова частка).

Наказом Міністерства юстиції України «Про невідкладні заходи щодо захисту прав громадян на території проведення антитерористичної операції» встановлено, що нотаріальні дії та державну реєстрацію речових прав та їх обтяжень на нерухоме майно, розташоване на території окупованих територій, здійснюють, відповідно, державні реєстратори речових прав на нерухоме майно органів державної реєстрації прав та приватні і державні нотаріуси неокупованих районів Ауганської та Донецької областей відповідно до законодавства [8].

Законом України «Про тимчасові заходи на період проведення антитерористичної операції» було встановлено, що в разі, якщо останнім місцем проживання спадкодавця 6 населений пункт, на території якого органи державної влади тимчасово не здійснюють або здійснюють не в повному обсязі свої повноваження, місцем відкриття спадщини є місце подання першої заяви, що свідчить про волевиявлення щодо успадкованого майна, спадкоємців, виконавців заповіту, осіб, зацікавлених в охороні успадкованого майна, або вимог кредиторів. Простіше кажучи, спадкоємці можуть звернутися до будь-якого нотаріуса на території України, підконтрольної української влади, із заявою про прийняття спадщини [9].

Для того, щоб звертатися до нотаріуса із заявою про прийняття спадщини, як мінімум необхідно отримати свідоцтво про смерть спадкодавця. Однак на території АТО призупинено проведення державної реєстрації актів цивільного стану, в тому числі і видача свідоцтва про смерть. Проведення реєстрації актів цивільного стану здійснюеться будь-яким відділом державної реєстрації актів цивільного стану, що знаходяться за межами окупованої території. Довідки про причини смерті або інші «документи», видані окупаційною владою, не створюють жодних правових наслідків і не реєструються в відповідних реєстрах. У цій ситуації спадкоємцям потрібно ініціювати судовий процес для отримання рішення суду про встановлення факту смерті спадкодавця. Рішення суду за результатами розгляду справи не замінюе собою свідоцтво про смерть, а є лише підставою для його отримання.

\section{Висновки}

Слід зазначити, що в цей час науковцями та законодавцем проведена слабка аналітична робота матеріалів судової та нотаріальної практики, відсутні керівні роз'яснення вищих судових органів з проблемних питань спадкового права на окупованих та підконтрольних територіях, що створює додаткові можливості для зловживань, збільшення числа судових спорів, що виникають 3 приводу заповітів. Крім того, залишаються нереалізованими надані спадкодавцю можливості у зв'язку з недостатньою проінформованістю громадян про свої права та процедурою захисту спадкових прав. Рекомендовано внесення змін до законодавства щодо можливості продовження термінів для прийняття спадщини від спадкодавця, останнє місце проживання або нерухоме майно якого перебуває в зоні АТО. 


\section{Цивільне, підприсмницьке, господарське та трудове право}

\section{Література}

1. Цивільний кодекс України: Кодекс України від 16.01.200 3 року. № 435-IV. Дата оновлення: 16.10.2020. URL: https:// zakon.rada.gov.ua/laws/show/435-15\# Text (дата звернення: 01.12.2020).

1. Про забезпечення прав і свобод громадян та правовий режим на тимчасово окупованій території України: Закон України від 03.07.2020, № 720-IX - ВВР. 2014.№ 26. Ст. 892.

2. Про особливості державної політики із забезпечення державного суверенітету України на тимчасово окупованих територіях у Донецькій та Ауганській областях: Закон України від 26.11.2020 № 948-IX. BВР. 2018. № 10. Ст. 54.

3. Фулей Т.I. Застосування практики Європейського суду з прав людини при здійсненні правосуддя: Науково-методичний посібник для суддів. - 2-ге вид. випр., допов. К., 2015. 208 с.

4. Про тимчасові заходи на період проведення антитерористичної операції: Закон України від 27.12.2019 № 371-IX. BВP. 2014. № 44. Ст. 2040.

5. Конвенція про правову допомогу та правові відносини у цивільних, сімейних та кримінальних справах від 22.03.1993. Офіційний вісник України, 2005, №44, ст. 2824.

6. Федорич I.Я. Здійснення права на спадкування за цивільним законодавством України: дис... канд. юрид. наук: 08.05.2018 / Навчально-науковий юридичний інститут ДВНЗ «Прикарпатський національний університет імені Василя Стефаника». Івано-Франківськ, 2018. 236 с.

7. Про невідкладні заходи щодо захисту прав громадян на території проведення антитерористичної операції: Наказ Міністерства юстиції України 17 червня 2014 р. за № 640/25417. URL: https://zakon.rada.gov. ua/laws/show/z0640-14\# Техt (дата звернення: 29.11.2020)

8. Про тимчасові заходи на період проведення антитерористичної операції: Закон України від 27.12.2019 року№ 371-IX. URL: https://zakon.rada.gov.ua/ laws/show/1669-18\#Text (дата звернення: 12.12.2020)

\section{Chuikova V., Goncharova A. PROBLEMS OF INHERITANCE IN THE ANTI-TERRORIST OPERATION ZONE AND IN THE OCCUPIED TERRITORIES}

In this article, the authors reveal the issue of inheritance in the anti-terrorist operation zone and in the occupied territories. Innovations that came into force in 2018 are taken into account. It is noted that the occupied territories in Donetsk and Luhansk oblasts are recognized as parts of the territory of Ukraine, within which the armed forces of the Russian Federation and the occupation administration of the Russian Federation have established and exercise general control. The temporary occupation of the territories of Ukraine by the Russian Federation, regardless of its duration, is illegal and does not create any territorial rights for the Russian Federation. Within the temporarily occupied territories there is a special procedure for ensuring the rights and freedoms of the civilian population, defined by the legislation of Ukraine. Therefore, the procedure for registration of inheritance is unchanged throughout Ukraine

The information on the order of inheritance by law, by will and at the conclusion of the inheritance agreement was analyzed. Emphasis is placed on the fact that inheritance is not only a derivative way of ownership, but also, universal succession - the transfer of the whole set of rights, responsibilities, things from the deceased to the heirs.

At the same time, timely and clear fulfillment of one's obligations provides an opportunity to draw up an inheritance in a timely manner, in accordance with the law. Inheritance by will occurs if the deceased person made a will before death and it is valid. In his absence there is an inheritance by law. Inheritance by law takes place in the following cases: absence of a will; invalidation of the will; the death of the heirs specified in the will before the opening of the inheritance or their refusal to accept the inheritance; the testator revoked a previously made will and left no new one; the will was declared invalid by a court; if the will does not cover all the property belonging to the testator 
The activities of the armed forces of the Russian Federation and the occupation administration of the Russian Federation are illegal, and any act issued in connection with such activities is invalid and does not create any legal consequences, except for documents confirming the birth or death of a person in the temporarily occupied territories. in accordance with the application for state registration of a person's birth and the application for state registration of a person's death.

As a result of the occupation of part of the territory of Ukraine, from March 2014, territories with disputed status appeared in its composition. The inclusion of the occupied territories of Ukraine in the Russian Federation has received neither international nor foreign recognition. Accordingly, for other countries and their jurisdictions, including in the field of inheritance law, the application of Russian law in these territories has no legal consequences, including in terms of proper- ty relations and inheritance. The exercise of the right to inherit characterizes the attitude of the subject in which this right arose to the right itself and the legal consequences of its implementation. The right to inherit consists of powers that have arisen in connection with the opening of the inheritance and the call of the person to inherit, on the basis of a will (will) or law. The will of a person forms a set of his future powers, which also the legislator refers to the category of exercising the right to inherit.

Registration of civil status acts is carried out by any department of state registration of civil status acts located outside the occupied territory. Certificates of cause of death or other "documents" issued by the occupying power do not create any legal consequences and are not registered in the relevant registers..

Key words: heir, testator, inheritance, inheritance legislation, certificate of the right to inheritance, legal regime. 